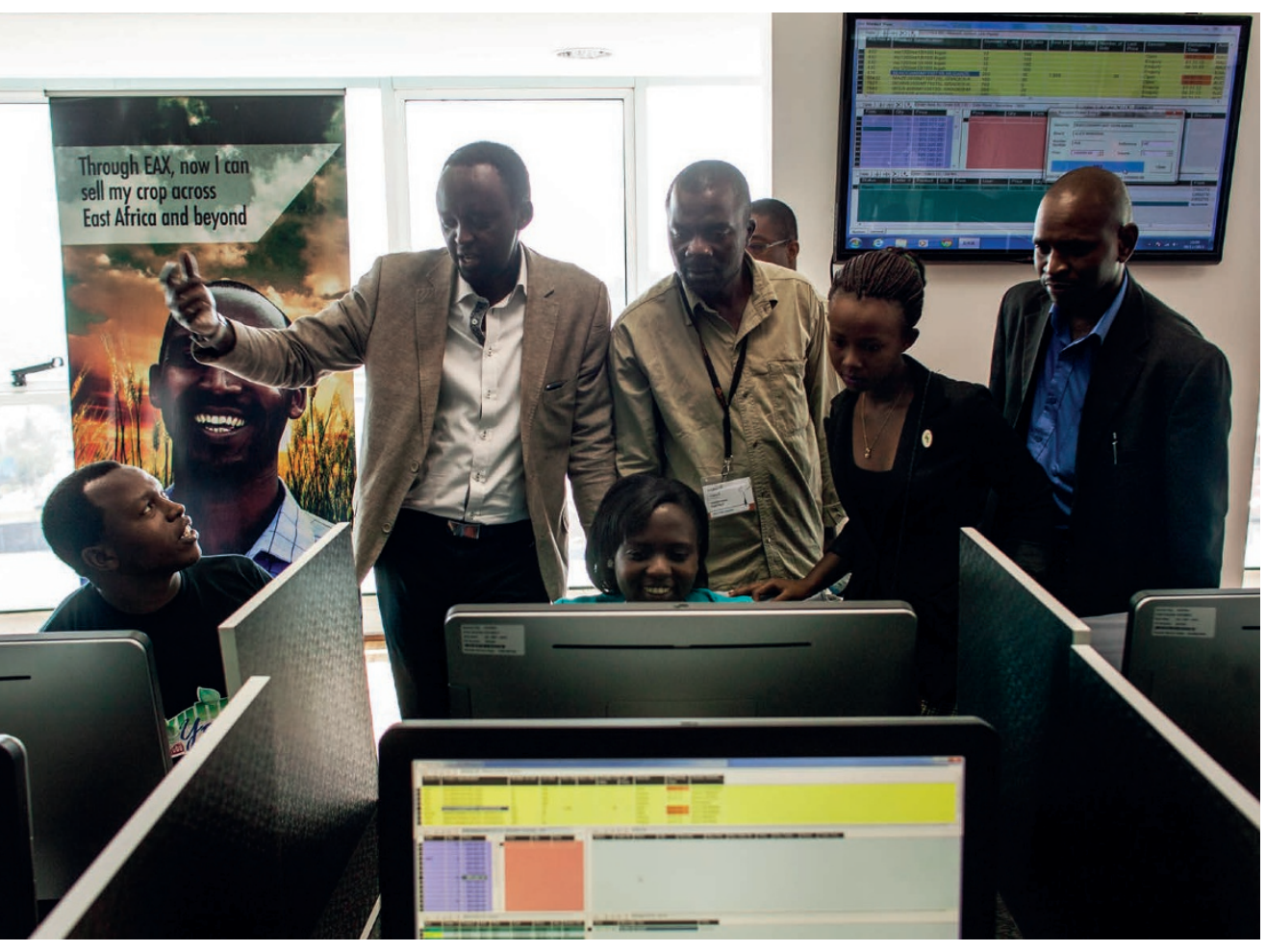

Technology specialists learn to use software at the East Africa Exchange in Kigali, Rwanda.

\title{
RWANDA
}

\section{From killing fields to technopolis}

\section{Two decades after the genocide in Rwanda, the country is harnessing science and technology to rebuild its economy.}

\section{BY LINDA NORDLING}

$\mathrm{F}$ irst-time visitors to Kigali, Rwanda’s capital, usually remark that they cannot believe they are in a country that a little over 20 years was in the midst of a civil war. The 1994 genocide against the Tutsi resulted in the slaughter of up to one million people - around $15 \%$ of the population. But the landlocked country is developing rapidly. Where gravel roads once dominated, paved streets are now the rule. Internet connections are fast and stable. Buildings are constructed at breakneck speed, and airy, reliably scheduled public buses and shuttles have replaced cramped, unpredictable minivans.

For Jimmy Gasore, a Rwandan physics graduate who left the country in 2011 to pursue a $\mathrm{PhD}$ at the Massachusetts Institute of Technology in Cambridge, each trip home throws up new advances. For instance, the year he left, he had to spend ten hours on a bus to Uganda's capital, Kampala, to register for the standardized tests needed for his MIT application, but these exams can now be taken all over Rwanda - an indication of the central role that the government has given to science and education in the country's development strategy.

Rwanda has used investment in science, technology and innovation as a springboard to grow and diversify its economy. Between 1996 and 2015, its per capita gross domestic product (GDP) more than tripled to US $\$ 1,756$ - outpacing some bigger and more resource-rich African countries with fast-growing economies, such as Kenya, whose per capita GDP merely doubled over the same period. As a result, Rwanda is often held up as a model of what can be achieved if clear ambitions are backed up with strong political leadership. Although the country's economic activity remains modest - its private sector is still largely informal - the rapid modernization of its infrastructure is attracting both foreigners and Rwandan expats to the country.

Gasore is one of them. In 2017, after he attains his $\mathrm{PhD}$, he is planning to return to Rwanda to keep working on the cutting-edge climate observatory that he helped to set up which is perched 2,500 metres above sea level on Mount Mugogo. The station, the first of its kind in Africa, uses high-frequency monitoring systems to detect greenhouse gases and air pollutants all across the continent.

He says that scientists like him see opportunities in Rwanda. "There are more institutions to teach in, more start-ups to join and more people to partner with. In short, it creates a sort of market in science and technology," he says.

\section{A SCIENCE-LED RECOVERY}

Rwanda's remarkable journey started after the genocide, when stitching the war-torn nation back together seemed like an insurmountable task. The country's economy, which was small and agriculture-based to begin with, was in tatters. Farm workers had fled their homes and abandoned their fields. Worse, the social fabric of the country had unravelled: schools, health centres, and water and transport infrastructure were in ruins, and survivors had to live along side perpetrators.

Rwanda's new leaders realized that education, including science education, would be essential to the nation's rebirth. The country needed a positive development trajectory to follow, but it had no oil or gas reserves, no diamonds or valuable minerals, and no vast forests suitable for logging to exploit. What it did have was the offer of assistance from the international community, which had failed to prevent the atrocities in the country, and a population thirsty for peace and prosperity.

Rwandan President Paul Kagame, who will seek re-election for his third term in 2017, has driven the science push. After becoming president in 2000, one of his first moves was to appoint Romain Murenzi as science minister. The Rwandan mathematical physicist had been working on multidimensional continuous wavelet transforms - which can be used in image compression - at Clark Atlanta University in Georgia, where he had spent most of the 1990s. When he took up the post in 2001, Murenzi started by drawing up a national policy on science, technology and innovation. The policy, adopted in 2005 , focused not on doing science as an end in itself, but as a vehicle for development. It emphasized that Rwanda should not try to 'reinvent the wheel', but apply existing knowledge to solve its national challenges.

"What was special about Rwanda was that their ideas were so on target," says Alfred Watkins, who led the team from the World Bank that helped to draw up Rwanda's science and technology plans. In his experience, many governments of developing countries want 
their national science plans to feature prestigious projects. "We were not talking about studying black holes or doing wonderful scientific research. The main gist of it was to create practical solutions to mundane everyday problems: how to improve agricultural yield, how to provide clean drinking water, how to manage the country's geothermal resources intelligently," Watkins says.

One such problem was how to combat a pest that was damaging the country's coffee crops - a key source of income for more than 400,000 Rwandan farmers. Potato taste defect (PTD) leaves coffee with a mealy potato taste, and is linked to the antestia bug (Antestiopsis spp.). Until a few years ago, little was known about how the defect occurred and why. But in 2011, working with the US-based non-profit the Global Knowledge Initiative (GKI), Rwandan researchers established a global network of scientists, as well as companies such as Starbucks - which took part in taste experiments - to study the scourge. Although the network has yet to eliminate PTD, the research, including successful work on insecticides, combined with an awareness-raising programme for farmers, has led to a decline in its occurrence, says Andrew Gerard, a programme officer at the GKI.

In addition to recruiting scientists to solve Rwandan problems, Kagame and Murenzi have developed a culture of using science and innovation to inform evidence-based policymaking in government. During the mid-2000s, Murenzi would hold a meeting of government ministers every two or three months; one by one, he would ask them how they were using science, technology and innovation to carry out and improve their work. Watkins would also attend these meetings to provide World Bank support.

In the first few meetings, the ministers' answers were feeble, Watkins recalls. But it didn't take long for their responses to become competent. The agriculture minister would talk about terracing fields to prevent erosion or using tissue culture to enhance crop yields. "Previously, they didn't know what to say," he recalls. "Now all of a sudden, they had examples."

Agriculture was a key focus for science and education investments. Agricultural research and development spending by the government and non-profit organizations grew by nearly $50 \%$, from $\$ 18.6$ million in 2005 to $\$ 27.2$ million in 2011. Most African countries struggle with an ageing academic population, but twothirds of Rwanda's agricultural researchers are under the age of 41 years - one of the youngest pools in Africa.

Kagame also revamped the higher-education system in an effort to produce the graduates with the science, technology, engineering and mathematics skills that the country now

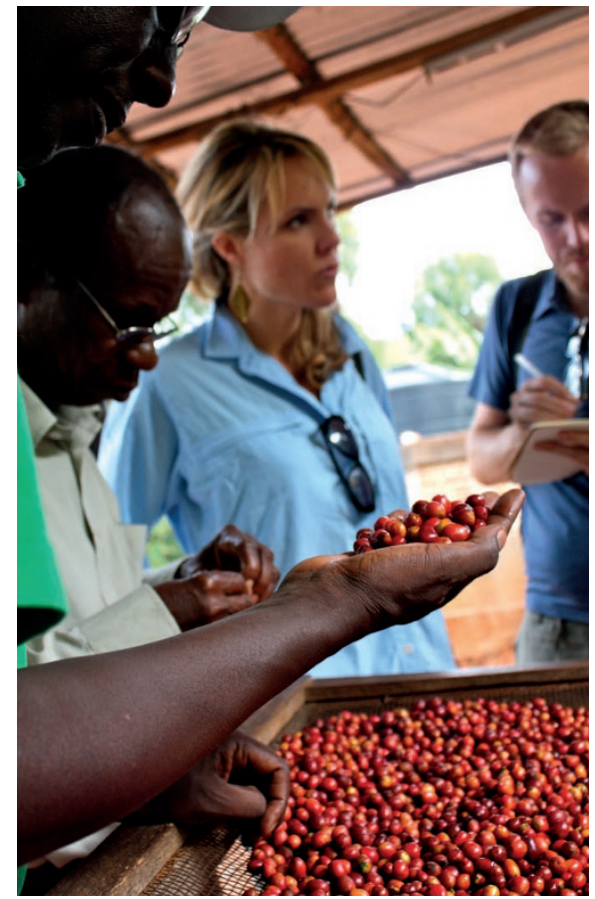

A team from the Global Knowledge Initiative inspects coffee cherries.

needed. The country's seven tertiary institutions were merged into a single University of Rwanda, which was launched in 2013. The university has 14 campuses nationwide and more than 30,000 students - one-fifth of them studying science or engineering.

Mindful of Rwanda's limited financial resources, the government looked to the rest of the world to help it pursue its development goals. And some of the partnerships it formed were groundbreaking. In 2012, Carnegie Mellon University (CMU) in Pittsburgh, Pennsylvania, became the first world-ranked university to establish a campus in central Africa.

"CMU didn't choose Rwanda, Rwanda chose CMU," says Bruce Krogh, director of CMU-R, as the partnership is known. The foundations were laid when Rwanda's government approached CMU in 2007; the university was selected partly because of its high performance in computer science and information technology. The first crop of students graduated in 2014. In 2016, CMU-R had 480 applications from 19 African countries for its August intake. Krogh says that of these, $40-50$ students will be accepted.

In the future, Rwanda will have to stand more firmly on its own feet. As its scientific and technological prowess grows, so does its ambitions for scientific output and excellence. The national university is aiming high: in a draft strategic plan published this year, it aims to be among the top ten universities in Africa by 2025.

\section{MOUNTAINTOP VIEW}

Climate science is one area in which Rwanda is busy carving out a globally competitive niche. Data from the climate observatory on Mount Mugogo will open up a new frontier in climate science - historically, Africa has been very poorly covered by climate-data surveys, says Ronald Prinn, an atmospheric scientist at MIT and one of the people behind the observatory. The observatory will be the first African station to join the Advanced Global Atmospheric Gases Experiment, which has a dozen other stations spread across the world, from the Norwegian archipelago of Svalbard to Tasmania in Australia. The Rwandan station can track pollution and greenhouse gases across vast ranges - from South Africa to the Middle East and even the western coast of India.

It is hoped that the higher peak Mount Karisimbi, which towers 4,500 metres over sea level, will be the final site for the observatory. But access to this mountain is tricky, especially because its slopes are home to Rwanda's endangered mountain gorillas. A proposal is under discussion for a cable car that could transport researchers to the top, as well as serve ecotourists - Rwanda is also looking to expand its tourism industry.

Despite its many advances, Rwanda still faces major problems. For one, the country remains very poor: in 2014 , less than one in five Rwandans had access to electricity, and about $40 \%$ of Rwandans lived in poverty, according to the United Nations Development Programme. And the small size of the country's private sector means that employment can be hard to come by. For example, Krogh says that although most graduates from CMU-R land jobs easily, they struggle to find work in Rwanda. This is something that President Kagame has indicated needs to change. But economic growth will need to come from inside the country, and from business investments, to a greater extent than it has hitherto. There are indications that international financial aid, on which the country depends on for some $30-40 \%$ of its budget, may be drying up. What the country does have, however, is loyal young people. "I have never met students so serious about giving back to their country as in Rwanda," says Prinn.

To Gasore, whose generation has been shaped by Rwanda's science, technology and engineering drive, the future is bright. Since his undergraduate degree, he has observed a shift in the courses being taught, from theoretical to more practical and applied science, as access to laboratories and computers has increased. This, he thinks, will further encourage Rwandans to innovate, which in turn will help the economy to grow. "It's very clear," Gasore says, "that technology and vocational training will be the real seeds for the science- and technology-based economy." -

Linda Nordling is a freelance science writer in Cape Town, South Africa. 